\title{
13
}

\section{Multi-level Governance in the Lake Eyre Basin: Meeting in the Middle?}

\author{
Kate Andrews
}

\section{Introduction}

Scale is inescapable in natural resource management (NRM), which operates up and down geographical scales and levels of governance - from paddock to river basin, land manager to federal politician and local to federal government, and all within a complex and constantly changing social-ecological system.

The community-based Lake Eyre Basin (LEB) catchment management framework (1995-2002) and the government-based Lake Eyre Basin Intergovernmental Agreement (2001-ongoing) are examples of collaborative multi-level governance (MLG) in a multi-actor, multi-level system. Both demonstrate two elements of MLG: establishing the vertical and horizontal links between scales and levels and involving a diversity of players, including communities, governments and industry stakeholders. Comparing the government and the non-government models, however, reveals several differences between them, including scope and integration of issues, level of involvement of non-government actors and hierarchy, control and distribution of power. Analysing these two processes leads to a number of questions, including should we expect more of MLG mechanisms than vertical connection between scales and a diversity of 
players? As discussed by Bache and Flinders (2004), perhaps MLG should represent models that create new forms of accountability and empowered relationships between people and their institutions.

The benefits of MLG have been documented and have particular relevance to NRM:

From a management perspective, evidence is accumulating that supports the hypothesis that those systems that more consciously address scale issues and the dynamic linkages across levels are more successful at (1) assessing problems and (2) finding solutions that are more politically and ecologically sustainable (Cash et al. 2006).

This paper introduces the LEB community initiative and the intergovernmental agreement, explaining how they sit within the national NRM framework. It describes changes and challenges for the processes over time, compares the characteristics of the two initiatives and, finally, questions how and whether both constitute actual MLG.

Lake Eyre is a huge, ephemeral salt lake in the centre of Australia. Its catchment, the internally draining LEB, stretches across more than 1.2 million square kilometres (Smith 1998), a larger area than France and Germany combined, and contains fewer than 60,000 people, making it one of the most sparsely populated areas in the world. The basin is a biophysically defined region that covers a large portion of central Australia, including substantial chunks of Queensland, South Australia, the Northern Territory and a small area of New South Wales. It cuts across multiple political and administrative jurisdictions and socially defined regions, at many levels. As a result, any NRM process contends with the differences between state legislation, structures, policy and cultures.

The size of the basin, its diverse landscape and values, and the multiple political jurisdictions that it covers, guarantee that its management must incorporate a multitude of different needs and perspectives including pastoralists on family- or company-owned properties; Aboriginal communities and individuals with historical and/or traditional connections to the land; conservationists and the organisations that they work for, such as the Australian Conservation Foundation; the mining and petroleum industries, from individuals engaged in Wild West-style opal mining to the huge, high-tech operations of BHP Billiton and Santos; residents of small and remote towns who work for local councils or are involved in the tourism industry; scientists from many disciplines and institutions; 
three layers of government in four major jurisdictions and multiple local governments and state agencies; and landcare and industry groups. This incomplete list captures the confusion of players with a stake in the future of the LEB.

Proposed World Heritage listing by the Australian Government in the early 1990s generated passion and controversy between these groups and, although listing did not proceed and the Australian Government decided that community efforts could best protect the basin, the battle left a gulf between people who had lost trust in each other.

\section{The Lake Eyre Basin Community Initiative, 1995-2002}

The LEB initiative began in 1995 at a public meeting in Birdsville, Queensland, a one-pub town on the edge of the Simpson Desert. Concerned by conflict between different groups and the potential for World Heritage listing, community members wanted to bring together these different interests to work towards sustainable use and management of the natural resources in the basin.

A cross-section of interest groups was invited to this first public meeting and many different organisations and individuals attended, including government officers and community members. A lot of work went into this pre-negotiation - deciding upon the relevant players, making the contacts, encouraging attendance, employing a professional facilitator and planning the meeting. This preparation ensured that participants were able to agree to move to a next stage. A steering group was formed representing all the different interests, with a two-year sunset clause and no fait accompli to continue in any form after that. The steering group was established to explore the issues and future management options of the LEB, particularly through the lens of catchment management, and then to hold another public workshop in 1997 to make a decision as to whether and how to proceed.

As an indication of their commitment to this decision, various organisations and industries contributed start-up funds. Subsequent funding was provided from the Commonwealth Government and the South Australian and Queensland state governments. 
As the first meeting was organised by LEB community members (albeit with government agency support), the elected steering group and the subsequent consultation process was less frequently seen as being an imposition from 'outside' or 'government', which is regularly an important concern in the independent culture of the outback. Having the steering group comprised of the various stakeholders created ownership and credibility within the region and encouraged diverse stakeholders to support, rather than undermine, the process. Individuals and various interest groups had a chance to be involved in listening, learning and determining the outcomes.

Given the unusual and extreme natural and geographic characteristics of the basin, it was obvious that it would not be successful to import or impose a framework from anywhere else. Even establishing an organisation was not without difficulties - the terms of reference for the steering group were to explore future options rather than to take concrete steps. It was necessary for the group to first design an appropriate framework to give participants an opportunity to learn about catchment management and collaborative decision-making, and to think through whether and how those process could be used in the LEB to encourage ownership and the implementation of any decision that resulted.

In 1996, while employed as the project officer working for the diverse community steering group, I embarked upon a process of basinwide consultation, asking people questions like 'What are the major natural resource management issues in the basin?' and 'If catchment management was to work in the basin what would it look like?' Over 20 workshops were held across the basin, along with countless smaller meetings and conversations - over kitchen tables or campfires, tea or beer. People designed their ideal regional community structure for the basin, addressing the challenges and issues of the region and the pros and cons of catchment management. From this, a draft options paper was produced and, after further input and feedback (much of it verbal and derived from the informal conversations that suited some of the stakeholder groups), a final options paper of people's opinions and organisational designs was distributed (LEBSG 1997a). The steering group also produced an issues paper exploring some of the key concerns that had been raised during the consultation: managing pest animals and weeds, management and use of our natural river systems, floodplain grazing and conserving biological diversity (LEBSG 1997b). 
Much to the surprise of many, given the bullish independence and individualism that defines outback culture, in 1997 the steering group's final public workshop in Birdsville successfully negotiated to establish a basin-wide integrated catchment management organisation. The potential structure was thrashed out again in detail at the workshop and a mix-and-match version of the designs that had been presented in the options paper was developed (LEBSG 1997a). A transition group was appointed to manage the establishment of the organisation that once again included all stakeholders. The Commonwealth minister of the environment was on hand to announce substantial funding from his government's Natural Heritage Trust.

Participants agreed upon a number of key principles for the catchment process, which would have been unlikely without the previous year of participation, relationship-building and negotiation. First and foremost was inclusiveness. Participants agreed to all stakeholders being involved, from outback pastoralists to urban conservationists, mining companies to Indigenous Australian communities, and scientists to bureaucrats. Likewise, it was agreed that the organisation should address the management of all natural resources and, where possible, the links to economic and social issues. The logic of the biophysical boundaries was seen to supersede the political and administrative borders. It was agreed that the political and administrative borders should be ignored so as to bring together communities and governments of all levels (local, state and federal) within the basin in a multi-state organisation. As a local pastoralist commented in one workshop, 'Water doesn't stop at the state border and nor do feral pigs'. The process of designing and establishing the LEB organisation began as a consultative process and evolved into a participatory one (Andrews 2000, 2003a).

Moving from an idealised and abstract structure on paper to a living, breathing organisation was the next make-or-break stage. Establishing participatory and fair catchment committees over enormous and diverse catchments and then the overarching Lake Eyre Basin Coordinating Group (LEBCG) raised many challenges and tensions, including at one public meeting a request from a local government participant to vote on whether we should run the meeting by consensus or not (we did not vote, and the meeting, as all others, was consensus based). Just as it is counterproductive to artificially divide people from the town where they 
shop, the catchment/sub-catchment committee boundaries were defined to take into account social catchments with the biophysical (Andrews 2003b).

The basin-wide group and the two first cross-border catchment committees then worked to develop long-term strategies, build partnerships and find funding for on-ground work, such as cross-border pig culls.

From uncertain beginnings as a widely scattered steering group in 1995, by 2000 the LEBCG, of which I was the first CEO, was an incorporated body with an office and staff based in Longreach, Queensland; substantial community involvement; catchment-wide management strategies; and the role of community advisory committee to the newly formed Lake Eyre Basin Ministerial Forum, which was established by an intergovernmental agreement signed between the Australian, South Australian and Queensland governments (Andrews 2003a).

\section{The Lake Eyre Basin Intergovernmental Agreement, 1995-2013}

While the above process was underway, the stakeholders in the community initiative were also providing input to a government negotiation to establish an agreement between the Commonwealth, Queensland and South Australian governments to cooperatively manage the major internal river systems that flow from Queensland to South Australia. A heads of agreement was signed by these three governments in 1997 to provide for the development of an intergovernmental agreement. Further consultation occurred in parallel with the development of the community initiative, and further governmental negotiation, and the LEB Intergovernmental Agreement was signed in 2000 in Birdsville, with the launch of the community initiative's first LEB strategy, and Cooper and GeorginaDiamantina catchment plans.

Once ratified by the three governments, the agreement came into effect in 2001, with the Northern Territory Government joining and signing the agreement in 2004. The agreement established the ministerial forum and a senior officers group with two associated advisory committees - the community advisory committee and the scientific advisory panel. 
The LEB community initiative, through the steering group and then the LEB coordinating group, encouraged this agreement for a number of years. A regular request from people throughout the process was to link the community structure directly to formal government processes, such as providing a community committee with direct access to the highest political decision-makers through a ministerial forum. This was achieved in 2000 with the agreement that the LEBCG, as the overarching community group, performs the role of a community advisory committee to the ministerial forum. The coordinating group performed this role until late 2002, at which point regional NRM arrangements changed across the country. In late 2003 , the ministerial forum appointed members to the community advisory committee.

The Lake Eyre Basin Intergovernmental Agreement

(LEB Intergovernmental Agreement 2000):

provides for the sustainable management of the water and related natural resources associated with cross-border river systems in the Lake Eyre Basin to avoid downstream impacts on associated environmental, economic and social values (3).

The purpose of the agreement is:

to provide for the development or adoption, and implementation of Policies and Strategies concerning water and related natural resources in the Lake Eyre Basin Agreement Area to avoid or eliminate so far as reasonably practicable adverse cross-border impacts (6).

The ministerial forum is also required to review the condition of all watercourses and catchments within the LEB agreement area.

The ninth and 10th principles of the agreement state:

that the collective local knowledge and experience of the Lake Eyre Basin Agreement Area communities are of significant value; and that decisions need to be based on the best available scientific and technical information together with the collective local knowledge and experience of communities within the Lake Eyre Basin Agreement Area (7).

Part Four of the agreement addresses the 'Roles of the parties', outlining the responsibilities and interests first of the Commonwealth and then of the states. Interests or stakeholders other than governments, not being signatories to the agreement, are not addressed. A section, however, does address 'Community advice and representation', stating that 'the Ministerial 
Forum will ensure that it has satisfactory access to community advice in relation to matters relevant to this Agreement' (LEB Intergovernmental Agreement 2000: 9), illustrating how the arrangements maintain the existing power balance. Advice can be provided by the scientific and community committees to the ministerial forum; however, they do not formally participate in the decision-making. Additionally, as the states and territory have statutory responsibilities for NRM, the agreement relies upon their cooperation and commitment to function. A state has no obligation to do so.

\section{The borders are back: Establishing state- based regional organisations, 2002-13}

In the early 2000s, Australia embarked upon regionalisation of NRM across the country, building upon the statutory-based catchment management bodies that already existed in some states. This constituted a substantial change and established a markedly different regime. Boundaries for each of the 56 regions were established in agreements between the Commonwealth, state and territory governments between December 2002 and June 2004, and bilateral agreements were signed as part of the second phase of the Natural Heritage Trust. Where there were no existing state-based arrangements, non-government organisations mainly incorporated associations - were established. In the cases where non-government regional organisations already existed, such as the Blackwood Catchment Group in Western Australia or the LEBCG, they were bypassed or subsumed within the new arrangements.

These nationally supported regional arrangements continued through a change of federal government in 2007 and the establishment of a new national program, Caring for our Country. The bilateral arrangements between the states/territories and the Australian Government ceased with the new program; however, the Australian Government continued to fund regional bodies directly and through open competitive arrangements. Regional bodies and their collective or legislative arrangements continue to evolve differently in different jurisdictions.

Figure 13.1 summarises the roles of the various levels of government, regional bodies and community groups as they existed in 2011 . 
13. MULTI-LEVEL GOVERNANCE IN THE LAKE EYRE BASIN

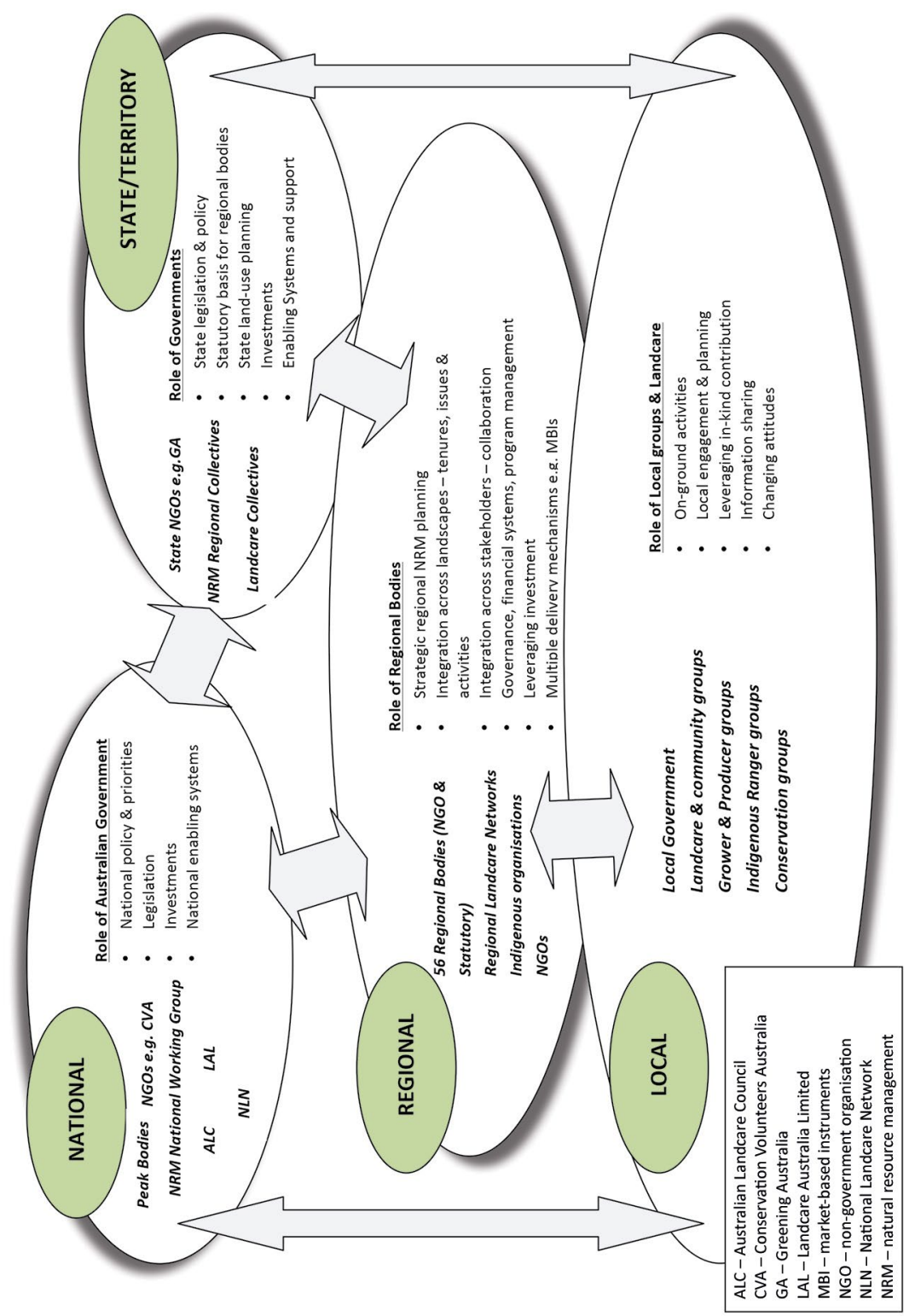

Figure 13.1: NRM MLG structures and roles in 2011

Source: Andrews (2011) 
In the case of the LEB, support for the cross-border community organisation of the LEBCG finished and state-based regional bodies were formed - Desert Channels in the LEB portion of Queensland, the SA Arid Lands regional body in north-east South Australia and the Territory Natural Resource Management Board in the Northern Territory.

As a result of these changes, the LEBCG no longer performed the role of community advisory committee for the intergovernmental agreement; rather, the committee was separately constituted by government. Given the small pool of available people, however, it retained some of the original participants. Rather than the committee membership being derived from a process of community consultation, they were ministerial appointments. The two cross-border catchment groups continued to exist under the auspices of Desert Channels Queensland; however, there was little material or logistical support for them and they had no explicit role in the new arrangements. For example, five years after writing the original catchment plan, the Georgina-Diamantina Catchment Committee revisited their plan at a meeting in Boulia. Having no coordinator and no logistical support, the plan was not distributed beforehand and the Desert Channels representative was unable to advise the committee as to what, if any, of the actions and targets had been achieved. The group ended by re-endorsing the plan, which they wholeheartedly supported, but were left in limbo as to what was happening with suggested actions (I was, coincidentally, present at the meeting). It seems likely that the catchment committees will become less and less engaged or relevant as they struggle on with little support.

In the five-year review of the Lake Eyre Basin Agreement (URS 2007), it was recognised that the state-based regional bodies were conspicuous by their absence in the arrangements. Recommendations were made to involve representatives of regional bodies in the community advisory committee. The committee is now constituted of a prescribed range of interests including those of Indigenous Australian communities, pastoral and conservation, and the regional bodies nominate for a number of the positions and hold a position as board members. While chair of Territory Natural Resource Management, I was the board's representative on the committee. 


\section{Comparing the community initiative and the intergovernmental agreement}

Table 13.1 outlines and compares the major characteristics of the two processes described above.

Table 13.1: Comparison of the Lake Eyre Basin Intergovernmental Agreement and community initiative

\begin{tabular}{|c|c|c|}
\hline Characteristics & $\begin{array}{l}\text { LEB Intergovernmental } \\
\text { Agreement }\end{array}$ & LEB community initiative \\
\hline $\begin{array}{l}\text { Geographical } \\
\text { coverage }\end{array}$ & $\begin{array}{l}\text { Initially limited to the Georgina- } \\
\text { Diamantina and Cooper Creek river } \\
\text { systems in Queensland and South } \\
\text { Australia, ending at Lake Eyre } \\
\text { (signed in 2000); the NT portion of } \\
\text { the basin included from } 2004\end{array}$ & $\begin{array}{l}\text { Working to encompass the } \\
\text { entirety of the basin, including } \\
\text { the western rivers of Lake Eyre } \\
\text { in South Australia and the NSW } \\
\text { portion }\end{array}$ \\
\hline $\begin{array}{l}\text { Who initiated, } \\
\text { participated } \\
\text { and funded }\end{array}$ & $\begin{array}{l}\text { Initiated by governments, } \\
\text { negotiated between governments, } \\
\text { government consultation of } \\
\text { stakeholders and communities }\end{array}$ & $\begin{array}{l}\text { Initiated by local residents, } \\
\text { negotiated between } \\
\text { stakeholders with participation } \\
\text { of governments, initial cash } \\
\text { and in kind contribution from } \\
\text { industries, local government } \\
\text { and individuals, ongoing majority } \\
\text { of funding from governments } \\
\text { and in kind from individuals and } \\
\text { some companies }\end{array}$ \\
\hline $\begin{array}{l}\text { Initial motivation } \\
\text { or governance } \\
\text { challenge }\end{array}$ & $\begin{array}{l}\text { Cross-border water management } \\
\text { - proposed water developments } \\
\text { in the Queensland portion of } \\
\text { the basin that would impact } \\
\text { upon South Australia, such as } \\
\text { the proposal to grow cotton at } \\
\text { Currareva near Windorah }\end{array}$ & $\begin{array}{l}\text { Originally, the proposed World } \\
\text { Heritage Listing of the LEB, } \\
\text { then the proposed irrigation } \\
\text { development for the cultivation } \\
\text { of cotton at Currareva on the } \\
\text { Cooper }\end{array}$ \\
\hline $\begin{array}{l}\text { Structure and } \\
\text { levels }\end{array}$ & $\begin{array}{l}\text { The ministerial forum consists } \\
\text { of the Australian Government } \\
\text { and three state and territory } \\
\text { governments, a senior officer's } \\
\text { group and two groups to advise } \\
\text { the ministerial forum - the } \\
\text { community advisory committee } \\
\text { and the scientific advisory panel }\end{array}$ & $\begin{array}{l}\text { Three nested levels: basin-wide } \\
\text { coordinating group, catchment } \\
\text { management groups, and sub- } \\
\text { catchment or working groups } \\
\text { as required (determined by local } \\
\text { residents or participants) }\end{array}$ \\
\hline Status or rules & Legislatively based & $\begin{array}{l}\text { A non-government organisation } \\
\text { established as an incorporated } \\
\text { association with objectives, } \\
\text { principles and 'rules' established } \\
\text { in a participatory, consensus- } \\
\text { based process for each level }\end{array}$ \\
\hline
\end{tabular}




\begin{tabular}{|c|c|c|}
\hline Characteristics & $\begin{array}{l}\text { LEB Intergovernmental } \\
\text { Agreement }\end{array}$ & LEB community initiative \\
\hline $\begin{array}{l}\text { Scope of issues } \\
\text { and policy }\end{array}$ & $\begin{array}{l}\text { Emphasis on water - the } \\
\text { agreement provides for the } \\
\text { sustainable management of the } \\
\text { water and related natural resources } \\
\text { associated with cross-border river } \\
\text { systems in the Lake Eyre Basin, } \\
\text { the scope and interpretation has } \\
\text { broadened over time }\end{array}$ & $\begin{array}{l}\text { Emphasis on integrated } \\
\text { catchment management } \\
\text { (all natural resources and } \\
\text { social and economic factors), } \\
\text { basin-wide and catchment } \\
\text { management strategies } \\
\text { addressing NRM issues }\end{array}$ \\
\hline Objectives & $\begin{array}{l}\text { The purpose of the agreement is } \\
\text { to provide for the development } \\
\text { or adoption, and implementation, } \\
\text { of policies and strategies } \\
\text { concerning water and related } \\
\text { natural resources in the Lake Eyre } \\
\text { Basin agreement area to avoid } \\
\text { or eliminate, so far as reasonably } \\
\text { practicable, adverse cross-border } \\
\text { impacts; under the agreement, } \\
\text { the Lake Eyre Basin Ministerial } \\
\text { Forum is required to review the } \\
\text { condition of all watercourses and } \\
\text { catchments within the Lake Eyre } \\
\text { Basin agreement area }\end{array}$ & $\begin{array}{l}\text { Coordinating group: to promote } \\
\text { ecological and economic } \\
\text { sustainability in the basin, } \\
\text { develop and communicate } \\
\text { a shared strategic vision across } \\
\text { the basin, provide a forum for } \\
\text { basin-wide issues, provide } \\
\text { a communication channel } \\
\text { with governments, integrate } \\
\text { priorities for action plans and } \\
\text { funding, facilitate knowledge } \\
\text { flow and development for the } \\
\text { basin, represent the catchments } \\
\text { on a national level } \\
\text { Catchment committees: } \\
\text { to maintain a focus on the } \\
\text { catchment perspective; work } \\
\text { for ecological, economic and } \\
\text { social sustainability within } \\
\text { the catchment; develop and } \\
\text { maintain a strategic planning } \\
\text { process, including compilation, } \\
\text { implementation and monitoring; } \\
\text { provide a forum for differing } \\
\text { opinions on issues within the } \\
\text { catchment, followed by a } \\
\text { decision-making process based } \\
\text { on best available information; } \\
\text { represent the catchment } \\
\text { perspective on a basin } \\
\text { level; involve the catchment } \\
\text { community }\end{array}$ \\
\hline
\end{tabular}




\begin{tabular}{|c|c|c|}
\hline Characteristics & $\begin{array}{l}\text { LEB Intergovernmental } \\
\text { Agreement }\end{array}$ & LEB community initiative \\
\hline $\begin{array}{l}\text { Participants } \\
\text { and role }\end{array}$ & $\begin{array}{l}\text { Ministerial forum: relevant minister } \\
\text { from each jurisdiction, meets once } \\
\text { a year } \\
\text { Community advisory committee: } \\
\text { to provide community advice to } \\
\text { government on water and related } \\
\text { natural resource issues in the } \\
\text { Lake Eyre Basin; appointed by } \\
\text { the ministerial forum; } 17 \text { members } \\
\text { representing community } \\
\text { stakeholders in the LEB, including } \\
\text { from regional NRM bodies, } \\
\text { Indigenous interests, pastoral, } \\
\text { petroleum and mining; meets twice } \\
\text { a year face-to-face } \\
\text { Scientific advisory panel: to } \\
\text { provide scientific advice to the } \\
\text { ministerial forum relevant to the } \\
\text { management of water and related } \\
\text { natural resources, in particular on } \\
\text { monitoring the condition of rivers } \\
\text { and catchments; appointed by the } \\
\text { ministerial forum } \\
\text { Senior officers group: senior } \\
\text { government officers from relevant } \\
\text { agencies in each jurisdiction, - } \\
\text { provides advice to the ministerial } \\
\text { forum and implements its } \\
\text { decisions } \\
\text { LEB Aboriginal forum: held every } \\
\text { two years to promote the input of } \\
\text { Indigenous Australians into policies } \\
\text { devised by the ministerial forum }\end{array}$ & $\begin{array}{l}\text { Catchment/regional committees } \\
\text { based upon biophysical } \\
\text { and social catchments and } \\
\text { which include sub-catchment } \\
\text { committees or local groups; } \\
\text { these provided membership to } \\
\text { the overarching Lake Eyre Basin } \\
\text { Coordinating Group, which also } \\
\text { included skills-based members } \\
\text { and government observers; the } \\
\text { Lake Eyre Basin Coordinating } \\
\text { Group acted as the community } \\
\text { advisory committee until } \\
\text { late } 2002\end{array}$ \\
\hline
\end{tabular}

Both processes demonstrate the two most obvious elements of MLG: establishing the vertical and horizontal links between scales and levels, and involving a diversity of players, including communities, governments and industry stakeholders.

A comparison also raises several differences between the processes as they relate to MLG, including the scope and integration of issues; level and type of involvement of non-government actors; and the hierarchy, control and distribution of power.

Scope refers to both the physical area and the issues covered. An obvious difference between the two processes addressing the management of LEB was their geographic scope. The intergovernmental agreement originally 
captured what was the main government concern at the time - the rivers that flowed (occasionally) from Queensland to South Australia. As documented above, however, the geographical area covered by the agreement has increased over time so as to better reflect the river basin as a whole. There was also an initial difference between the scope of the issues addressed by the two MLG processes in that the intergovernmental agreement focused on water management while the community process sought to integrate all natural resource issues and acknowledge the related social and economic factors.

Over time, the intergovernmental agreement has experienced 'scope creep' in that the development of the LEB Rivers Assessment Implementation Plan proposes a strategic adaptive management process that begins with developing a 'desired state of LEB landscape condition'. The second step in the plan narrows in again to riverine landscape condition and then, in later steps, broadens out to encompass LEB landscape form and function (Price et al. 2009). The implementation plan has developed from focusing on river health to a broader, more holistic landscape approach which goes some way to being an integrated NRM approach (the intent of the community initiative) where natural resources, such as water or vegetation or soil, are not dealt with in isolation but are understood as parts of a whole system. The approach of the LEB community initiative was to integrate catchment management (LEBSG 1997a; Andrews 1999a, 1999b, 2003a) and to ensure that people were an acknowledged part of the equation. The rivers assessment plan has been accepted in a modified form (a smaller budget) by the ministerial forum.

Equally as important as the scope of the MLG processes area and issues is the scope of its decisions. What decisions can the process address and by whom is this determined? Are these decisions relevant to non-government participants?

The level of community involvement is a characteristic that differs significantly between the intergovernmental agreement structure and the community initiative. With the disconnection between the intergovernmental agreement and the LEBCG, the participatory and nested community processes that supported the community advisory committee ceased. Currently, the LEB advisory committee meets twice a year. Social capital and networks that developed through the establishment of the LEB community catchment initiative mean there are individuals willing and able to participate, and strong connections between sectoral players and across jurisdictional borders. Some of the individuals 
participating in the advisory committee are those who helped design and establish the coordinating group and catchment committees. This continuity has underpinned the existing arrangement. As the inevitable occurs and members change, it will be interesting to see how the formal arrangements work without the same level of ongoing investment of social capital and relationships.

How does the contribution of individuals through an advisory committee become community involvement? How are those individuals supported to broader processes? In theory, formally involving the regional NRM bodies, as occurred in response to the URS review (2007), should achieve this; however, such involvement is hindered by a number of factors. The boundaries of the regional bodies are different and generally larger than the LEB alone, and regional priorities are set within this larger context. Regional bodies predominantly rely on government funding through a national NRM program that is separate to, and generally disconnected from, the LEB process. Funding priorities for that program are set at a national level. As the finances and activities of regional bodies are tied to the requirements of government funding and priorities, this restricts their ability to determine the location and focus of their projects. Thus, maintaining engagement and commitment is a constant challenge, particularly in the Northern Territory, where the regional body covers the entire jurisdiction, of which the LEB is only a small portion. Additionally, regional bodies have varied mechanisms, priorities and capacity for involving their stakeholders.

As the current regional model evolves, cooperative cross-border models are emerging, such as the Rangelands Alliance, which is the most relevant example to the LEB. Once again, though, the boundaries of the alliance stretch beyond the LEB and incorporate a large swathe of the rangelands, including the WA rangelands stretching right to the north-western coastline. Internally to the basin, cross-border catchment committees are continuing but with apparently little support and less relevance.

The LEB Community Advisory Committee and the Scientific Advisory Panel are advisory committees only; they do not have decision-making power. Sitting on a representative advisory committee with no decisionmaking power and a limited budget is a stark contrast to participating in a non-government organisation with the power to initiate projects and allocate funds. The LEB community initiative's nested processes helped create diverse community input, which resulted in a deeper and supported 
structure. While ministers hold ultimate decision-making power, the senior officers group has influence through managing the information that reaches ministers, including the framing of briefs and recommendations, the control of budgets and the running of the agreement process, and through the implementation of decisions, either via the secretariat or the relevant government agencies. There is a clear hierarchy and, less clear and overt, distribution of power and influence.

In the case of the LEB, is it possible to determine the influence of this circle of non-state actors who have participated in the process? What has resulted from their influence? Have the Lake Eyre Basin MLG processes resulted in outcomes that have differed from what would otherwise have been the case?

\section{Is it MLG?}

The ceding of state authority to non-democratically accountable processes has been discussed as a possible negative consequence of MLG (Termeer et al. 2010). This concern presupposes some redistribution of power away from elected representative government, either through direct decisionmaking or through influence, which raises the question of how much decision-making power is being redistributed, either up or down the levels of governance or to the non-state players. Once the talking is done, who actually makes the decisions? Bache and Flinders sum this up: 'a distinction must be drawn between multi-level governance and multilevel participation, where the latter notion signals greater involvement without effective influence', going on to say that this failure 'to address the continuing existence of structural inequalities' (2004: 204) may be a weakness in MLG that can perhaps be dealt with through clearer expectations of actors' influence as well as participation. Where does the power to make decisions lie in the structure or system? When Termeer et al. (2010: 29) say that 'the nature of multi-level governance is that it will conflict with existing norms of democratic legitimacy because it will go beyond the control of elected politicians or state executives', they provide a simple benchmark or criteria for determining whether the LEB Intergovernmental Agreement, a multi-level mechanism, is also MLG. In the case of the LEB Intergovernmental Agreement, the decisionmaking power resides with the ministerial forum and the senior officers group that advises the forum. 
Using Peters and Pierre's (2004) description of MLG as a basis on which to compare the LEB mechanisms reveals stark difference. They suggest four characteristics as defining MLG: a wide and diverse set of actors; non-hierarchical and not controlled from above; unconstrained by formal agreements or rules, so informal bargaining is as important as formal power; and largely ignores structure, focusing on process and outcomes. Of these descriptors, the community initiative accords with each while the intergovernmental agreement is only consistent with the first.

Both Termeer's and Peters and Pierre's work provide a basis for introductory discussion as to whether the two processes described in this paper are, in fact, MLG. Although they both established vertical and horizontal links between scales and levels, and involve a diversity of players, there was disparity in the participation of the non-government sector and in the way power was distributed. Evolving MLG, according to Bache and Flinders, needs 'new forms and models of accountability' that build new conduits between the public and institutions. This may involve reappraisal of democracy and the role of representative institutions. However, 'participation does not equate to power and the emergence of multi-level governance does not necessarily enhance the position of weaker social groups' (Bache and Flinders 2004: 205). Should we expect more of MLG mechanisms than vertical connection between scales and a diversity of players? Perhaps MLG should now represent models that create new forms of accountability and empowered relationships between people and their institutions.

\section{References}

Andrews, K. (1999a). Rivers in the Rangelands - What's Happening in the Lake Eyre Basin. Second Australian Stream Management Conference, 8-11 February, Adelaide, South Australia, pp. 15-20.

. (1999b). The Lake Eyre Basin Regional Initiative. In: Sustainable Regional Development - Final Report. Dore and Woodhill, Greening Australia Ltd.

. (2000). Case Study 6 - The Lake Eyre Basin Regional Initiative. In: Buchy, M., Ross, H. \& Proctor, W. (eds) Enhancing the Information Base on Participatory Approaches in Australian Natural Resource Management. Commissioned research under the Land and Water Resources Research and Development Corporation's Social and Institutional Research Program, Canberra. 
—_. (2003a). Negotiating a Future in the Lake Eyre Basin. Paper for the International Biennale on Negotiation, Negocia, Paris.

—. (2003b). Pelicans, Pubs and Politics - plenty of them all in the Lake Eyre Basin. In: Beef in the Outback - Planning for Profit. Proceedings of the 8th National Workshop of the Beef Improvement Association of Australia Ltd.

- (2011). Levels and Roles within the Natural Resource Management Regional Model. Working paper for Territory Natural Resource Management.

Bache, I. \& Flinders, M. (eds) (2004). Multi-level Governance. Oxford University Press. doi.org/10.1093/0199259259.001.0001

Cash, D.W., Adger, W., Berkes, F., Garden, P., Lebel, L., Olsson, P., Pritchard, L. \& Young, O. (2006). Scale and Cross-Scale Dynamics: governance and information in a multilevel world. Ecology and Society, 11(2): 8. doi.org/10.5751/ES-01759-110208

LEBCG (2000). A Future for All. Strategic Plans for the Lake Eyre Basin. Lake Eyre Basin Coordinating Group, Longreach, Queensland.

LEB Intergovernmental Agreement (2000). lakeeyrebasin.gov.au/ sitecollectionimages/71d27602-9826-4d4f-9004-fbc30cde225b/files/ leb-intergovernmental-agreement.pdf [Accessed: 9/11/2017].

LEBSG (1997a). Issues Paper. Lake Eyre Basin Steering Group, Longreach, Queensland.

—. (1997b). Options Paper. Lake Eyre Basin Steering Group, Longreach, Queensland.

Peters, G.B. \& Pierre, J. (2004). Multi-level Governance and Democracy: a 'Faustian bargain'? In: Bache, I. \& Flinders, M. (eds) Multi-level Governance. Oxford University Press. doi.org/10.1093/ 0199259259.003 .0005

Price, R., Thoms, M., Capon, S. \& Watkins, D. (2009). Lake Eyre Basin Rivers Assessment Implementation Plan Project Final Report. Lake Eyre Basin Ministerial Forum, www.lakeeyrebasin.gov.au/resources/ publications [Accessed: 22/1/2015]. 
Smith, D.I. (1998). Water in Australia: Resources and Management. Oxford University Press, Melbourne.

Termeer, C.J.A.M., Dewulf, A. \& van Lieshout, M. (2010). Disentangling Scale Approaches in Governance Research: comparing monocentric, multilevel, and adaptive governance. Ecology and Society, 15(4): 29. doi.org/10.5751/es-03798-150429

URS (2007). Review of the Lake Eyre Basin Intergovernmental Agreement. Prepared for the Commonwealth Department of Environment and Water Resources, Canberra, www.lakeeyrebasin. gov.au/sitecollectionimages/resources/2ab8837c-e4aa-48a0-ab67586004b57be5/files/review-final-report.pdf [Accessed: 20/10/17]. 
This text is taken from Multi-level Governance: Conceptual challenges and case studies from Australia, edited by Katherine A. Daniell and Adrian Kay, published 2017 by ANU Press, The Australian National University, Canberra, Australia.

dx.doi.org/10.22459/MG.11.2017.13 